\title{
Bovine Somatotropin and Rumen-Undegradable Protein Effects on Skeletal Growth in Prepubertal Dairy Heifers*
}

\author{
U. Moallem, ${ }^{1}$ G. E. Dahl, ${ }^{1}$ E. K. Duffey, ${ }^{1}$ A. V. Capuco, ${ }^{2}$ and R. A. Erdman ${ }^{1}$ \\ ${ }^{1}$ Department of Animal and Avian Sciences \\ University of Maryland, College Park 20742 \\ ${ }^{2}$ Bovine Functional Genomics Laboratory, \\ Animal and Natural Resources Institute \\ Agricultural Research Service, USDA, \\ Beltsville, MD 20705
}

\section{ABSTRACT}

The objectives of this study were to determine the effects of dietary rumen-undegradable protein (RUP) and bovine somatotropin (bST) during the period from weaning until puberty on body weight (BW) and skeletal growth rates and age at puberty. Fifty-one Holstein heifers at $90 \mathrm{~d}$ of age were randomly assigned to 4 treatment groups consisting of $0.1 \mathrm{mg} / \mathrm{kg} \mathrm{BW}$ per day of bST and $2 \%$ added dietary RUP (dry matter basis) applied in a $2 \times 2$ factorial design ( $\mathrm{n}=13$ per group, except bST with no RUP group, $n=12$ ). From 90 to 314 $\mathrm{d}$, bST increased average daily gain (ADG) by $0.07 \mathrm{~kg} /$ $\mathrm{d}$ and $\mathrm{BW}$ by $16.2 \mathrm{~kg}$, while added RUP increased $\mathrm{ADG}$ by $0.10 \mathrm{~kg} / \mathrm{d}$ and BW by $21.4 \mathrm{~kg}$. Both bST and added RUP effects on BW and ADG were additive. Skeletal growth rates, as measured by withers height $(\mathrm{WH})$ and hip height $(\mathrm{HH})$ were increased by both bST and added RUP. Somatotropin and RUP increased WH by 1.8 and $2.7 \mathrm{~cm}$ and hip height by 2.5 and $4.0 \mathrm{~cm}$, respectively, at $314 \mathrm{~d}$ of age. Growth curves showed that added RUP effects on rates of $\mathrm{BW}, \mathrm{WH}$, and $\mathrm{HH}$ growth were greatest from 90 to $150 \mathrm{~d}$ age and diminished thereafter, suggesting that protein was limiting during this time period. Conversely, bST effects tended to be greater as the heifers approached puberty, but only in the presence of added RUP. Age at puberty was not affected by treatment, averaging $314 \mathrm{~d}$ of age across treatments. From 314 to $644 \mathrm{~d}$ of age, rates of BW, WH, and $\mathrm{HH}$ growth were similar among treatment groups. However, treatment differences present at $314 \mathrm{~d}$ of age persisted through $644 \mathrm{~d}$ of age, more than 10 mo after treatments ceased. These results suggest that protein during the early postweaning period and bST during

\footnotetext{
Received October 28, 2004.

Accepted May 7, 2004.

Corresponding author: R. A. Erdman; e-mail: erdman@umd.edu.

*This research was supported by Research Grant Award No. US2921-97R from BARD, The United States-Israel Binational Agricultural Research and Development Fund.
}

the 200 to $300 \mathrm{~d}$ of age period just prior to puberty could be used to accelerate simultaneous increases in both BW and skeletal growth rates in dairy heifers without reducing age at puberty.

(Key words: dairy heifer, skeletal growth, somatotropin, rumen-undegradable protein)

Abbreviation key: ADG = average daily gain, $\mathbf{H H}=$ hip height, $\mathbf{M E}=$ metabolizable energy, $\mathbf{M P}=$ metabolizable protein, $\mathbf{W H}=$ withers height.

\section{INTRODUCTION}

Accelerating the growth of dairy heifers has the potential to increase profitability by reducing the time interval from birth to first calving, subsequently reducing feed, labor, housing, and other costs associated with raising replacement animals. However, previous work suggested that increasing rates of BW gain above 0.8 $\mathrm{kg} / \mathrm{d}$ during the period prior to puberty reduces mammary parenchymal tissue and increases mammary fat deposition (Sejrsen et al., 1982; Capuco et al., 1995), both factors are associated with lower milk production during the first lactation. However, it has been suggested that rapid rates of growth could be achieved without detrimental effects on subsequent milk production if rapid growth occurred with low rate of fat deposition (Capuco et al., 1995).

There is a positive relationship between BW at calving and milk production in first-lactation dairy cows (Clark and Touchberry, 1962; Hardville and Henderson, 1966; Hoffman, 1997). Keown and Everett (1986) observed that maximal first-lactation milk yield of Holstein replacement heifers occurred in animals that were between 590 and $635 \mathrm{~kg}$ at calving. Analysis of firstlactation production in commercial herds in Israel (Markusfeld and Ezra, 1993) showed that FCM yield and withers height at calving were positively related, whereas BW was negatively related to first-lactation FCM yield. This indicated that skeletal size rather than BW was strongly related to first-lactation milk yield. 
Furthermore, adequate skeleton size is needed to minimize dystocia during the first parturition (Markusfeld and Ezra, 1993). These observations were similar to those reported by Sieber et al. (1988), who also showed that withers height (WH) was a more important factor than BW in relation to first lactation milk yield.

Based on equations of Heinrichs and Hargrove (1987), nearly $80 \%$ of skeletal growth but only $50 \%$ of BW gain occurs during the time prior to puberty in dairy heifers. Rates of WH gain decrease from approximately $5 \mathrm{~cm} / \mathrm{mo}$ at $2 \mathrm{mo}$ of age to $1 \mathrm{~cm} / \mathrm{mo}$ during the postpuberty period. This suggests that the opportunity for increasing skeletal growth rate is greater during the time prior to puberty.

Somatotropin has increased $\mathrm{N}$ retention in steers, particularly when used in the presence of increased intestinal protein such as abomasal infusion of casein (Houseknecht et al., 1992; Bruckental et al., 1996). This suggests that lean tissue and possibly skeletal deposition may be enhanced by the simultaneous addition of bST and dietary RUP. In previous studies, positive effects of bST on growth of mammary parenchymal tissue were observed (Tucker, 1987; Sejrsen, 1994). Radcliff et al. (1997) and Grings et al. (1990) reported increased WH at puberty in dairy heifers treated with bST prior to puberty. Collectively, these experiments suggest that bST in combination with added RUP may provide a practical means to accelerate both $\mathrm{BW}$ and skeletal growth rates during the prepubertal period without increasing fat deposition and negatively impacting mammary development. The objectives of this study were to determine the effects of administration of bST and added dietary RUP prior to puberty on age at puberty and rates of BW gain and skeletal development in dairy heifers.

\section{MATERIAL AND METHODS}

\section{Animals and Diets}

The experimental protocol and animal care procedures were approved by the University of Maryland Institutional Animal Care and Use Committee and was conducted at Central Maryland Research and Education Center Dairy Unit located in Clarksville, Maryland. Fifty-one Holstein heifer calves, 29 and 22 each from 2 separate groups (replicates) of purchased calves were used in a growth experiment to evaluate the impact of prepubertal bST and added RUP on growth rates. Twelve heifers ( 1 or 2 from each treatment replicate) were slaughtered at 10 mo of age to collect data on body composition (Moallem et al., 2004). However, data from these animals were included in the present growth data set.
Table 1. Ingredients and chemical composition of the control and added RUP diets.

\begin{tabular}{lrc}
\hline & Control & Added RUP \\
\cline { 2 - 3 } & \multicolumn{2}{c}{ \% of DM } \\
\cline { 2 - 3 } Ingredients & 64.0 & 64.1 \\
Corn silage & 16.7 & 16.7 \\
Timothy hay & 2.2 & $\ldots .7$ \\
Corn grain, ground & 1.6 & 0.7 \\
Soybean meal & 13.1 & 13.1 \\
Excel soy & $\ldots$. & 4.8 \\
White fish meal & .2 & \\
Urea & 1.3 & $\ldots$ \\
Dicalcium phosphate & 0.3 & $\ldots .2$ \\
Limestone & 0.2 & 0.2 \\
NaCl & 0.4 & 0.4 \\
Vitamin and trace mineral & & \\
Chemical analysis & 46.2 & 46.3 \\
DM, \% & 14.9 & 16.9 \\
CP & 9.0 & 9.0 \\
RDP & 5.9 & 7.9 \\
RUP & 24.1 & 24.2 \\
ADF & 38.0 & 38.0 \\
NDF & 0.7 & 0.7 \\
Ca & 0.5 & 0.5 \\
P & &
\end{tabular}

${ }^{1}$ Excel soy, Excel Soybean Technologies, Oskaloosa, KS.

${ }^{2}$ Formulated to provide 2551 IU of vitamin A, 426 IU of vitamin $\mathrm{D}, 8.5 \mathrm{IU}$ of vitamin $\mathrm{E}$, $\mathrm{mg}$ of $\mathrm{Fe}, 15.4 \mathrm{mg}$ of $\mathrm{Zn}, 15.4 \mathrm{mg}$ of $\mathrm{Mn}, 7.7$ $\mathrm{mg}$ of $\mathrm{Cu}$ and $0.3 \mathrm{mg}$ of Se per $\mathrm{kg}$ of DM.

${ }^{3}$ Estimated using book values for degradability (NRC, 1989).

Calves were raised in individual calf hutches or pens until weaning at $60 \mathrm{~d}$ of age. Calves were raised on 4.5 $\mathrm{L} / \mathrm{d}$ of a commercial milk replacer and ad libitum water and starter mix until weaning at $60 \mathrm{~d}$ of age. After weaning, heifers were ad libitum fed starter mix and water until $90 \mathrm{~d}$ of age. At $90 \mathrm{~d}$ of age, heifers were randomly assigned to one of 4 treatments and transitioned onto a TMR fed daily at $1000 \mathrm{~h}$ until puberty. Treatments consisted of recombinant bST, with or without $2 \%$ added dietary RUP, applied in a $2 \times 2$ factorial design. The control diet was formulated according to 1989 NRC requirements to meet nutrient requirements including energy and protein needs for a $200-\mathrm{kg}$ largebreed heifer with a live-weight growth rate of $800 \mathrm{~g} / \mathrm{d}$. Diets were formulated to be equal in energy and RDP content but differed only in RUP content. The added RUP diets contained 16.9\% CP with 9.0\% RDP and 7.9\% RUP (DM basis) compared with $14.9 \% \mathrm{CP}$ with 9.0\% RDP and 5.9\% RUP in the control diet. Diets were fed as TMR. Ingredient and chemical composition of diets are shown in Table 1. Sustained release recombinant bST (Posilac, Monsanto Co., St Louis, MO), equivalent to $0.1 \mathrm{mg} / \mathrm{kg}$ BW per day, was injected subcutaneously (scapular region) every $14 \mathrm{~d}$ in bST-treated heifers. Heifers were housed in groups in pens within an open front building with a sawdust and barley straw bedded manure pack at the back and a concrete feeding 
alley at the front of each pen. Heifers within individual treatments and replicates were housed and fed in separate pens.

\section{Measurements}

Feed offered and feed refusals by pen were weighed and recorded daily, and DM content of TMR was determined weekly to estimate DMI. Body weight, WH, hip height (HH) and heart girth (HG) were measured on the same day every $2 \mathrm{wk}$ from 90 to $365 \mathrm{~d}$ of age and then monthly until $650 \mathrm{~d}$ of age. Withers height and $\mathrm{HH}$ were measured using vertical standard with crossbar HG by tape measure. Blood serum samples were collected by tail venipuncture from each heifer every 2 wk from $118 \mathrm{~d}$ age until puberty. Age at puberty was assessed by serum concentrations of progesterone, where puberty was determined as the age when 2 consecutive blood samples contained at least $1 \mathrm{ng}$ of progesterone/mL (Spicer et al., 1981). Circulating somatotropin, insulin, and IGF-1 were quantitated by radioimmunoassay (Connor et al., 1999; Auchtung et al., 2001) every $28 \mathrm{~d}$ using the same blood samples collected for progesterone analyses. Intra- and interassay coefficient of variation were 7.2 and $9.9 \%, 3.9$ and $7.4 \%$, and 8.3 and $9.7 \%$, respectively, for somatotropin, insulin, and IGF-1, respectively. After puberty, heifers from all treatments were housed and fed together according to NRC (1989) recommendations. When heifers reached $385 \mathrm{~kg} \mathrm{BW}$, they were observed for behavior estrus and artificially inseminated until pregnant.

\section{Statistical Analyses}

Body weight, $\mathrm{WH}, \mathrm{HH}$, and $\mathrm{HG}$ data collected on individual heifers within replicate beginning at 90 through $314 \mathrm{~d}$ age were fitted by regression analysis. Preliminary analysis, where data were fit to linear, quadratic, cubic, and quartic regression equations showed that there was no improvement in fit with equations of a higher order than quadratic as determined by Cp statistic (SAS, 2000) and $\mathrm{R}^{2}$. Quadratic regression equations were then used to predict specific point in time growth measurements, and the first derivatives of these equations were used to estimate instantaneous growth rates at specific ages during the experiment. Regression-predicted $\mathrm{BW}, \mathrm{WH}, \mathrm{HH}$, and $\mathrm{HG}$ and their corresponding instantaneous growth rates from 90 to $314 \mathrm{~d}$ of age were analyzed using the Mixed Procedure of SAS (SAS 8.0). The statistical model included effects of bST, RUP, RUP $\times$ bST, age, age $\times$ bST, age $\times$ RUP, and age $\times$ bST $\times$ RUP effects. Replicate within treatment was used as the random term for treatment effects, and replicate within time $\times$ treatment was used to test age and age $\times$ treatment interactions. Similarly, BW, WH, HH, and HG data from 314 until $644 \mathrm{~d}$ age was fitted and analyzed using the same procedures described for 90- to 314-d data. All growth measurements are reported as least square means. Serum somatotropin, insulin, and IGF-1 data were summarized by 28-d period from 118 to $314 \mathrm{~d}$ of age and analyzed using the Mixed Procedure SAS (SAS 8.0) as for growth data. Probability values $(P<0.05)$ were considered as significant, unless it was noted.

\section{RESULTS}

Table 2 shows feed intake and growth measurements by treatment between 90 and $314 \mathrm{~d}$ age. Dry matter intake was increased $(P<0.01)$ by 0.25 and $0.35 \mathrm{~kg} / \mathrm{d}$ in heifers treated with bST and added RUP, respectively. Age at puberty averaged $314 \mathrm{~d}$ across treatments and was not significantly influenced by added RUP or bST treatment.

Although initial BW at $90 \mathrm{~d}$ was not different between treatments, both bST $(P<0.02)$ and added RUP $(P$ $<0.01)$ increased BW at $314 \mathrm{~d}$ by 11.1 and $16.1 \mathrm{~kg}$, respectively, with no significant interaction $(P<0.3)$. Average daily gain (ADG) of BW was increased by 0.04 $\mathrm{kg} / \mathrm{d}$ by bST $(P=0.12)$ and $0.07 \mathrm{~kg} / \mathrm{d}(P<0.05)$ by RUP addition, and effects were additive as there was no bST by added RUP interaction. Figure 1 shows the interaction between age and treatment for ADG. The interaction of age and added RUP treatment $(P<0.02)$ suggests increased growth rates between 90 and $150 \mathrm{~d}$ were due to added RUP, and this response diminished with age. Conversely, increased BW gain with bST occurred after $200 \mathrm{~d}$ but only in the presence of added RUP.

Skeletal growth as measured by $\mathrm{WH}$ and $\mathrm{HH}$ from 90 to $314 \mathrm{~d}$ age are shown in Table 2. There were no differences among treatment groups in $\mathrm{WH}$ and $\mathrm{HH}$ at the beginning of the experiment ( $90 \mathrm{~d}$ ). However, $\mathrm{WH}$ was increased by $2.2 \mathrm{~cm}$ at $314 \mathrm{~d}$ in bST treated heifers $(P<0.07)$ and by $2.7 \mathrm{~cm}$ in added RUP heifers $(P<$ $0.02)$. Hip height was increased by $2.5 \mathrm{~cm}$ by bST $(P<$ $0.03)$ and $3.5 \mathrm{~cm}$ by added RUP $(P<0.01)$ at $314 \mathrm{~d}$. Rates of WH growth were increased by bST $0.009 \mathrm{~cm} /$ $\mathrm{d}(P<0.02)$ and $0.015 \mathrm{~cm} / \mathrm{d}$ by added RUP $(P<0.01)$ from 90 to $314 \mathrm{~d}$ age. No effect on rates of $\mathrm{HH}$ growth were observed for bST ( $P=0.13)$; however, it was significantly increased by added RUP $(P<0.02)$. Figures 2 and 3 show the rates for WH and HH growth $(\mathrm{cm} / \mathrm{d})$, respectively. As was the case for $\mathrm{ADG}$, rates of $\mathrm{HH}$ and WH were increased by added RUP during the period from 90 to $150 \mathrm{~d}$ of age $(P<0.001)$, while bST responses occurred from 200 to $300 \mathrm{~d}$ of age.

Posttreatment effects through $644 \mathrm{~d}$ of age on BW and skeletal growth are shown in Table 3. Due to increased 
Table 2. Least square means for DMI, age at puberty, BW, wither height (WH), hip height (HH), and heart girth (HG) and average rates of gain of these measurements from 90 to $314 \mathrm{~d}$ age for heifers fed control, injected with bST, fed added RUP, or the combination of RUP and bST (bSTRUP).

\begin{tabular}{|c|c|c|c|c|c|c|c|c|}
\hline \multirow[b]{2}{*}{ Item } & \multicolumn{4}{|c|}{ Treatment } & \multirow[b]{2}{*}{$\mathrm{SED}^{1}$} & \multicolumn{3}{|c|}{ Treatment effect $(P<)$} \\
\hline & Control & bST & RUP & bSTRUP & & bST & RUP & RUP*bST \\
\hline DMI, kg/d & 4.8 & 5.2 & 5.3 & 5.4 & 0.40 & 0.01 & 0.01 & 0.08 \\
\hline Puberty age, $d$ & 318 & 311 & 316 & 313 & 5.6 & 0.75 & 0.37 & 0.43 \\
\hline $\begin{array}{l}\text { BW } \\
90 \mathrm{~d}, \mathrm{~kg} \\
314 \mathrm{~d}, \mathrm{~kg} \\
90-314 \mathrm{~d}, \mathrm{~kg} / \mathrm{d}\end{array}$ & $\begin{array}{c}87.5 \\
289.3 \\
0.90\end{array}$ & $\begin{array}{c}90.5 \\
300.4 \\
0.94\end{array}$ & $\begin{array}{c}89.2 \\
305.4 \\
0.97\end{array}$ & $\begin{array}{c}87.4 \\
326.7 \\
1.07\end{array}$ & $\begin{array}{l}5.96 \\
4.31 \\
0.04\end{array}$ & $\begin{array}{l}0.92 \\
0.02 \\
0.12\end{array}$ & $\begin{array}{l}0.90 \\
0.01 \\
0.05\end{array}$ & $\begin{array}{l}0.71 \\
0.30 \\
0.40\end{array}$ \\
\hline $\begin{array}{l}\text { WH } \\
90 \mathrm{~d} \\
314 \mathrm{~d} \\
90-314 \mathrm{~d}, \mathrm{~cm} / \mathrm{d}\end{array}$ & $\begin{array}{c}84.3 \\
114.1 \\
0.139\end{array}$ & $\begin{array}{c}85.9 \\
116.3 \\
0.148\end{array}$ & $\begin{array}{c}84.6 \\
117.2 \\
0.154\end{array}$ & $\begin{array}{c}84.5 \\
118.6 \\
0.163\end{array}$ & $\begin{array}{l}0.50 \\
0.73 \\
0.01\end{array}$ & $\begin{array}{l}0.19 \\
0.07 \\
0.02\end{array}$ & $\begin{array}{l}0.34 \\
0.02 \\
0.01\end{array}$ & $\begin{array}{l}0.17 \\
0.62 \\
0.94\end{array}$ \\
\hline $\begin{array}{l}\mathrm{HH} \\
90 \mathrm{~d}, \mathrm{~cm} \\
314 \mathrm{~d}, \mathrm{~cm} \\
90-314 \mathrm{~d}, \mathrm{~cm} / \mathrm{d}\end{array}$ & $\begin{array}{c}88.9 \\
120.1 \\
0.137\end{array}$ & $\begin{array}{c}88.8 \\
121.9 \\
0.144\end{array}$ & $\begin{array}{c}88.5 \\
123.0 \\
0.151\end{array}$ & $\begin{array}{c}88.6 \\
126.1 \\
0.159\end{array}$ & $\begin{array}{l}0.58 \\
0.59 \\
0.01\end{array}$ & $\begin{array}{l}0.99 \\
0.03 \\
0.13\end{array}$ & $\begin{array}{l}0.63 \\
0.01 \\
0.02\end{array}$ & $\begin{array}{l}0.82 \\
0.88 \\
0.90\end{array}$ \\
\hline $\begin{array}{l}\mathrm{HG} \\
90 \mathrm{~d}, \mathrm{~cm} \\
314 \mathrm{~d}, \mathrm{~cm} \\
90-314 \mathrm{~d}, \mathrm{~cm} / \mathrm{d}\end{array}$ & $\begin{array}{l}100.1 \\
158.0 \\
0.258\end{array}$ & $\begin{array}{l}100.5 \\
158.1 \\
0.257\end{array}$ & $\begin{array}{r}100.6 \\
160.1 \\
0.266\end{array}$ & $\begin{array}{l}101.2 \\
164.4 \\
0.282\end{array}$ & $\begin{array}{l}2.27 \\
1.07 \\
0.01\end{array}$ & $\begin{array}{l}0.84 \\
0.11 \\
0.48\end{array}$ & $\begin{array}{l}0.82 \\
0.02 \\
0.18\end{array}$ & $\begin{array}{l}0.96 \\
0.12 \\
0.42\end{array}$ \\
\hline
\end{tabular}

${ }^{1}$ Standard error of the difference.

variability, there were no statistical differences in BW at $644 \mathrm{~d}$ of age, yet the magnitude of the differences among treatments were similar to those observed at $314 \mathrm{~d}$. Rate of BW gain was not different between treatments in the posttreatment period.

The difference in $\mathrm{WH}$ at the end of the treatment was still higher in added RUP heifers $(P<0.05)$ but was not significantly different in bST heifers $(P=0.12)$ at $644 \mathrm{~d}$ (Table 3). However, $\mathrm{HH}$ at $644 \mathrm{~d}$ of age was not statistically different by treatment. The magnitude of treatment effects on $\mathrm{WH}$ at $644 \mathrm{~d}$ was similar to

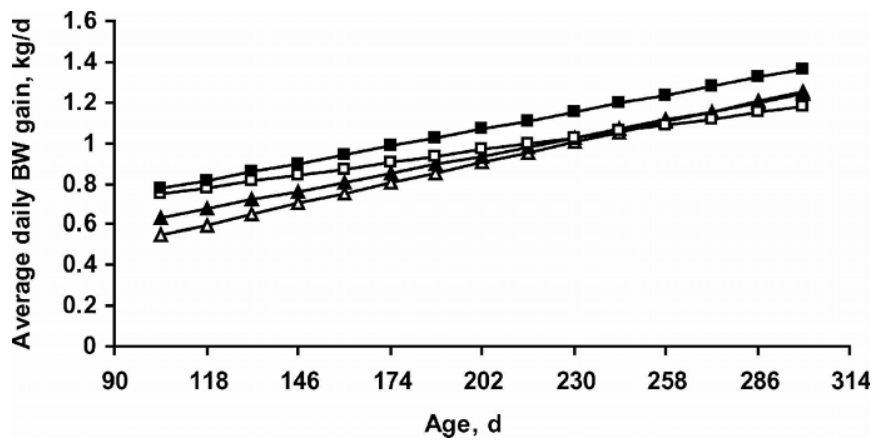

Figure 1. Least square means by age for average daily BW gain from 104 to $300 \mathrm{~d}$ of age for heifers fed the control diet $(\triangle)$, injected with bST ( $\mathbf{\Delta}$ ), fed added RUP ( $\square$ ), or the combination of RUP and bST( $\boldsymbol{\square})$. There were significant effects of age $(P<0.001)$ and the interaction of RUP by age $(P<0.02)$. (Standard error of the difference for treatment $\times$ age interaction $=0.023$.) that observed at $314 \mathrm{~d}$, whereas the differences in $\mathrm{HH}$ decreased during the posttreatment period. Prepubertal bST and added RUP did not affect rates of WH and $\mathrm{HH}$ gain from 314 to $644 \mathrm{~d}$. These responses suggested that differences in skeletal growth during the prepubertal period remained and were not compensated for during the posttreatment period. Compared with rates observed from 90 to $314 \mathrm{~d}$ (Table 2), rates of $\mathrm{WH}$ and $\mathrm{HH}$ gain were 3 -fold lower from 314 to $644 \mathrm{~d}$ of age (Table 3) than from 90 to $314 \mathrm{~d}$, demonstrating the reduced rate of skeletal growth during the postpubertal period.

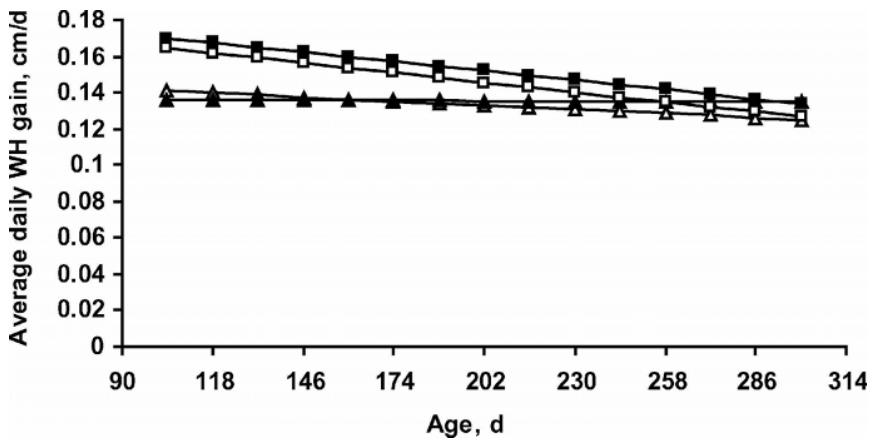

Figure 2. Least square means by age for average daily withers height (WH) gain from 104 to $300 \mathrm{~d}$ of age for heifers fed the control $\operatorname{diet}(\triangle)$, injected with bST $(\boldsymbol{\Delta})$, fed added RUP $(\square)$, or the combination of RUP and bST( $\mathbf{\square})$. There were significant effects of age $(P<0.001)$ and the interaction of RUP by age $(P<0.001)$. (Standard error of the difference for treatment $\times$ age interaction $=0.0048$.) 


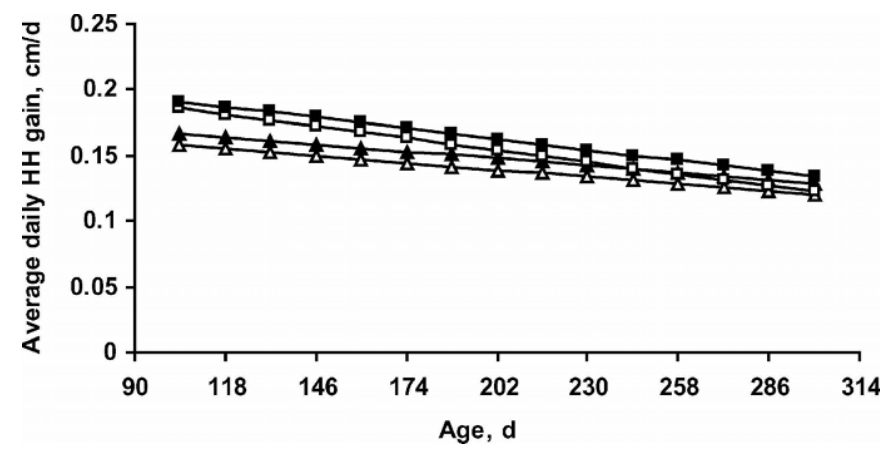

Figure 3. Least square means by age for average daily hip height $(\mathrm{HH})$ gain from 104 to $300 \mathrm{~d}$ of age for heifers fed the control diet $(\triangle)$, injected with bST $(\mathbf{\Delta})$, fed added RUP $(\square)$, or the combination of RUP and bST( $\boldsymbol{\square})$. There were significant effects of age $(P<0.001)$ but not for interactions of age $\times$ treatment. (Standard error of the difference for treatment by age interaction $=0.0098$.)

Figures 4, 5, and 6 show the serum somatotropin, insulin, and IGF-1 concentrations, respectively, by treatment in samples taken from 118 to $314 \mathrm{~d}$ of age. There was a bST by RUP interaction $(P=0.036)$ for insulin, whereas bST alone reduced serum insulin, while the combination of bST and added RUP resulted in higher insulin concentrations. As expected, serum somatotropin was increased by bST treatment $(P<$ 0.001 ), while somatotropin concentrations were lower $(P<0.03)$ when added RUP was fed with bST compared with bST treatment alone. Serum IGF-1 concentrations were increased by bST $(P<0.06)$ and RUP $(P<0.006)$, possibly reflecting the improved plane of nutrition due to added RUP and the direct effects of bST to stimulate IGF-1 production by the liver.

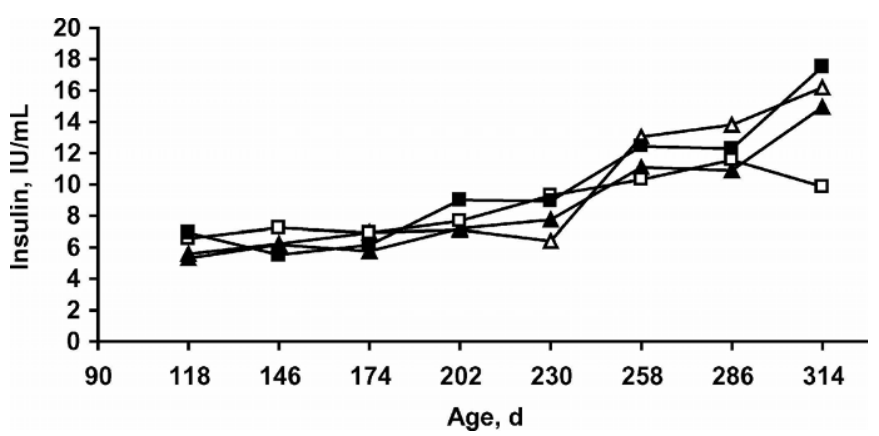

Figure 4. Least square means by age for serum insulin (IU/mL) from 118 to $314 \mathrm{~d}$ of age for heifers fed the control diet $(\triangle)$, injected with bovine somatotropin (bST) ( $\mathbf{\Delta})$, fed added RUP $(\square)$, or the combination of RUP and bST( $\square)$. There were significant effects of age $(P$ $<0.001)$, bST by RUP $(P=0.036)$ and age $\times$ treatment interactions $(P<0.001)$. (The standard error of the difference for treatment and age by treatment interactions were 1.04 and 1.83 , respectively.)

\section{DISCUSSION}

Rates of BW and skeletal growth reported in Figures 1 to 3 indicate differences in the timing of responses to added RUP and bST treatment. In comparison to bST, responses to added RUP were much greater at a younger age, while responses to bST effects were greater at the end the growth period but only in the presence of added RUP. This suggests that protein was the main factor limiting growth early. To determine whether protein truly was limiting, both metabolizable energy (ME) and metabolizable protein (MP) allowable growth rates were determined based on group feed intake, BW, and environmental temperature data according to NRC (2001) requirements for dairy heifers. Figure 7 shows the ME and MP allowable growth in

Table 3. Least square means for BW, wither height (WH), hip height (HH), and heart girth (HG) and average rates of postpubertal gain (314 to $644 \mathrm{~d}$ age) in heifers that were fed control, injected with bST, fed added RUP, or the combination of RUP and bST (bSTRUP) from 90 to $314 \mathrm{~d}$ age.

\begin{tabular}{|c|c|c|c|c|c|c|c|c|}
\hline \multirow[b]{2}{*}{ Item } & \multicolumn{4}{|c|}{ Treatment } & \multirow[b]{2}{*}{$\mathrm{SED}^{1}$} & \multicolumn{3}{|c|}{ Treatment effect $(P<)$} \\
\hline & Control & $\mathrm{bST}$ & RUP & bSTRUP & & $\mathrm{bST}$ & RUP & RUP*bST \\
\hline \multicolumn{9}{|l|}{ BW } \\
\hline $644 \mathrm{~d}, \mathrm{~kg}$ & 491.3 & 502.7 & 499.5 & 532.1 & 17.41 & 0.26 & 0.33 & 0.56 \\
\hline $314-644 \mathrm{~d}, \mathrm{~kg} / \mathrm{d}$ & 0.55 & 0.60 & 0.56 & 0.57 & 0.033 & 0.43 & 0.71 & 0.53 \\
\hline \multicolumn{9}{|l|}{ WH } \\
\hline $644 \mathrm{~d}, \mathrm{~cm}$ & 131.3 & 133.5 & 134.2 & 135.7 & 0.97 & 0.12 & 0.05 & 0.69 \\
\hline $314-644 \mathrm{~d}, \mathrm{~cm} / \mathrm{d}$ & 0.050 & 0.055 & 0.050 & 0.049 & 0.0039 & 0.64 & 0.50 & 0.47 \\
\hline \multicolumn{9}{|l|}{$\mathrm{HH}$} \\
\hline $644 \mathrm{~d}, \mathrm{~cm}$ & 138.3 & 139.4 & 140.1 & 140.6 & 1.21 & 0.53 & 0.29 & 0.83 \\
\hline $314-644 \mathrm{~d}, \mathrm{~cm} / \mathrm{d}$ & 0.050 & 0.052 & 0.050 & 0.045 & 0.0024 & 0.54 & 0.24 & 0.21 \\
\hline \multicolumn{9}{|l|}{$\mathrm{HG}$} \\
\hline $644 \mathrm{~d}, \mathrm{~cm}$ & 194.2 & 195.6 & 193.4 & 196.2 & 2.24 & 0.41 & 0.98 & 0.77 \\
\hline $314-644 \mathrm{~d}, \mathrm{~cm} / \mathrm{d}$ & 0.103 & 0.116 & 0.104 & 0.097 & 0.0044 & 0.49 & 0.12 & 0.10 \\
\hline
\end{tabular}

${ }^{1}$ Standard error of the difference. 


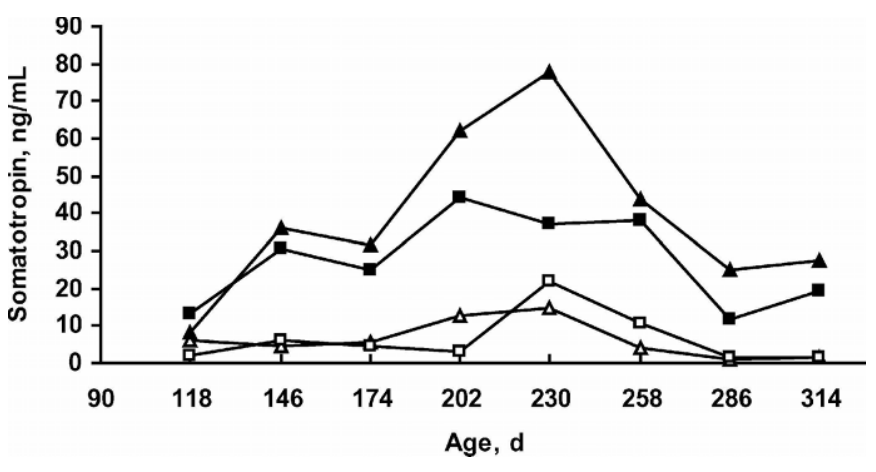

Figure 5. Least square means by age for serum somatotropin (ng/ $\mathrm{mL}$ ) from 118 to $314 \mathrm{~d}$ of age for heifers fed the control diet $(\triangle)$, injected with bovine somatotropin (bST) $(\mathbf{\Lambda})$, fed added RUP $(\square)$, or the combination of RUP and bST( $\square)$. There were significant effects of bST $(P<0.001)$, age $(P<0.001)$ and bST by age $(P<0.03)$, while there was a trend $(P=0.056)$ for the bST $\times$ RUP interaction. (The standard errors of the difference for treatment and age by treatment interactions were 8.3 and 10.8 , respectively.)

comparison to measured growth rates. For control and bST treatments alone (panels A and B), MP allowable gain was similar to actual BW gain from 100 to $190 \mathrm{~d}$ age. Thereafter, MP allowable gain exceeded actual gain and ME allowable gain closely paralleled actual gain. For heifers fed added RUP (panels C and D), ME allowable gain closely paralleled actual gain, while MP allowable gain exceeded actual gain for all but the first $50 \mathrm{~d}$ of the experiment. These observations coincide with increased rates of $\mathrm{BW}, \mathrm{WH}$, and $\mathrm{HH}$ growth with added RUP early (Figures 1 to 3 ). Because growth rates were first limited by protein from 90 to $190 \mathrm{~d}$, animals could respond to bST only when the protein limitation was removed. Alternatively, endogenous GH declines

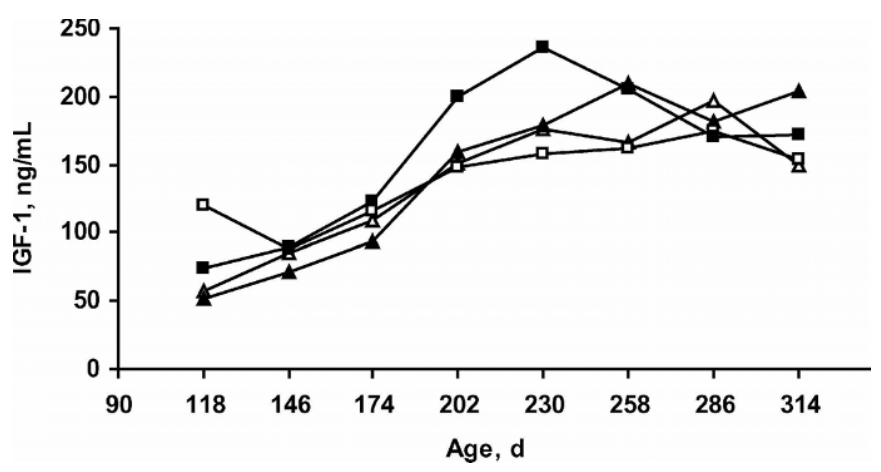

Figure 6. Least square means by age for serum insulin-like growth factor-1 (IGF-1) (ng/mL) from 118 to $314 \mathrm{~d}$ of age for heifers fed the control diet $(\triangle)$, injected with bovine somatotropin (bST) $(\boldsymbol{\Delta})$, fed added RUP $(\square)$, or the combination of RUP and bST( $\square)$. There were significant effects of RUP $(P<0.006)$, age $(P<0.001)$ and bST by age $(P<0.01)$ and a trend $(P=0.064)$ for bST effects. (The standard errors of the difference for treatment and age by treatment interactions were 19.0 and 24.1 , respectively). from birth, and thus elevation of circulating GH by exogenous bST at earlier ages may have less impact relative to effects observed in older animals.

The increases in ADG due to treatment in this experiment were modest $(0.04$ to $0.17 \mathrm{~kg} / \mathrm{d})$ compared with those observed in recent experiments in which dietary energy (Van Amburgh et al., 1998) or a combination of high protein and high energy with or without bST were used (Radcliff et al., 1997, 2000). In those experiments, ADG was increased by 0.33 to $0.42 \mathrm{~kg} / \mathrm{d}$ compared with controls during the prepubertal period (Radcliff et al., 1997, 2000; Van Amburgh et al., 1998). Conversely, WH was increased by 2.2 to $4.5 \mathrm{~cm}$ by bST, RUP, or bST plus RUP at $314 \mathrm{~d}$ in our experiment, while in other experiments (Radcliff et al., 1997, 2000; Van Amburgh et al., 1998) increased energy or the combination of increased energy and protein decreased skeletal size. This difference was primarily because either age at puberty or the age at the preselected BW at breeding was reduced by accelerated growth in these other experiments. Only when the combination of high energy and high protein was fed in conjunction with bST, was an increase in WH observed (Radcliff et al., 2000).

In contrast to experiments that evaluated the effect of increased energy density, Lammers and Heinrichs (2000) observed a $0.019 \mathrm{~cm} / \mathrm{d}$ increase in WH gain by increasing dietary protein from 11.8 to $15.6 \%$, similar to the $0.015 \mathrm{~cm} / \mathrm{d}$ increase observed with $2 \%$ added RUP in the present experiment, from 14.9 to $16.9 \% \mathrm{CP}$. As with the present experiment, they observed increased skeletal growth rates with only a small increase in $\mathrm{ADG}$ $(0.1 \mathrm{~kg} / \mathrm{d})$. The bST plus RUP treatment in our experiment resulted in a $0.024 \mathrm{~cm} / \mathrm{d}$ increase in growth rate, while rates of BW gain were increased by only $0.17 \mathrm{~kg} /$ d compared with controls. The results of this experiment and of Lammers and Heinrichs (2000) suggest that skeletal growth rate during the prepubertal period can be altered without necessarily causing large increases in BW gain.

Accelerated BW and skeletal growth during the prepubertal period was achieved in the current study, without affecting age of puberty (Table 2). This is in contrast with other reports (McShane et al., 1989; Schillo et al., 1992; Radcliff et al., 1997), where accelerated growth decreased age at puberty. In our study, all diets contained similar ME content, and the dietary influence on growth was achieved by added RUP, whereas in previous studies increases in body growth and early onset of puberty were achieved by high-energy diets. Nutritional effects on timing of puberty may have been a result of an effect on pulsatile release of LH (Kurz et al., 1990). A hypothetical model for explaining the mechanism of nutritional effects on the onset of puberty in growing heifers was suggested by Schillo et al. (1992). 

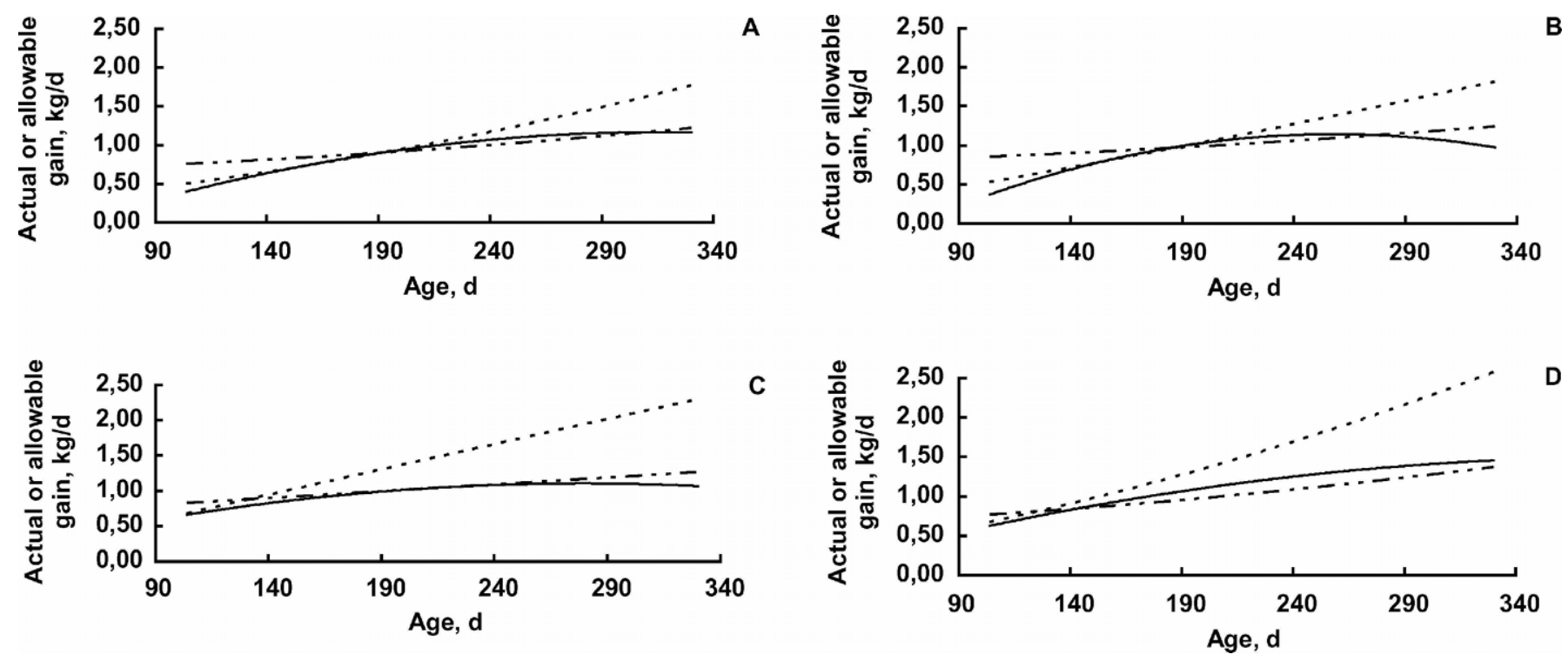

Figure 7. Comparison of average daily gain ( $\mathrm{kg} / \mathrm{d})$ (solid line) versus metabolizable energy allowable gain (dot-dash line) and metabolizable protein allowable gain (dotted line) for heifers fed the control diet (panel A), injected with bST (panel B), fed added RUP (panel C), or the combination of RUP and bST (panel D).

In this model, the energy status and metabolism play the primary role in triggering LH secretion, which leads to sexual puberty. Because accelerated growth in our work was achieved by added protein and bST rather than energy, it would follow from the Schillo et al. model (1992) that protein does not trigger LH secretion. Therefore, onset of puberty was not affected. The large increases in rates of skeletal growth that we observed with only modest increases in rates of BW gain suggest that increased growth consisted of primarily lean body tissue rather than fat deposition. This might also explain why age at puberty was unaffected by bST or added RUP treatment. This hypothesis is also supported by the work of Radcliff et al. (1997), where the onset of puberty was decreased by $47 \mathrm{~d}$ in heifers fed high-energy diets, while the decrease was only $24 \mathrm{~d}$ with bST.

Previous studies of Markusfeld and Ezra (1993) and Sieber et al. (1988) showed that WH was more highly corrected to first-lactation milk yield than BW. Equations of Heinrichs and Hargrove (1987), developed from data for growing Holstein heifers, suggest that rate of WH growth is approximately $3.3 \mathrm{~cm} / \mathrm{mo}$ from to 2 to 9 mo of age (prepubertal period). During the next $6 \mathrm{mo}$, WH growth rate drops gradually to $1.2 \mathrm{~cm} / \mathrm{mo}$ and then remains constant until 23 mo of age (Heinrichs and Hargrove, 1987). This postpubertal decline in skeletal growth rate is likely the result of the effect of reproductive hormones on growth plate closure in bones. Similarly, across treatments in this experiment, $\mathrm{WH}$ growth rate was $4.5 \mathrm{~cm} / \mathrm{mo}$ between 90 and $300 \mathrm{~d}$ of age, and then dropped to $1.7 \mathrm{~cm} / \mathrm{mo}$ from 314 to $644 \mathrm{~d}$ of age.

Because skeletal growth rate after puberty is lower than prior to puberty, opportunities for increasing skeletal growth rate and therefore greater skeletal size at calving are likely to be greatest during the prepubertal period. The impact of such a strategy would occur when not only prepubertal skeletal growth was increased but also when the age at puberty was either unaffected or possibly even extended. In this experiment, increased rates of $\mathrm{WH}$ and $\mathrm{HH}$ growth were achieved with bST and added RUP treatment without decreasing age at puberty. The persistence of these treatment differences at $644 \mathrm{~d}$ suggests that these nutritional and hormonal manipulations would promote an extended period of rapid prepubertal skeletal growth.

\section{REFERENCES}

Auchtung, T. L., E. E. Connor, S. M. Barao, L. W. Douglass, and G. E. Dahl. 2001. Use of growth hormone response to growth hormonereleasing hormone (GHRH) to determine growth potential in beef heifers. J. Anim. Sci. 79:1566-1572.

Bruckental, I., G. Huntington, C. Kirk-Baer, and R. Erdman. 1997. The effect of abomasal infusion of casein and recombinant somatotropin hormone injection on nitrogen balance and amino acid fluxes in portal-drained viscera, net hepatic and total splanchnic blood in Holstein steers. J. Anim. Sci. 75:1119-1129.

Capuco, A. V., J. J. Smith, D. R. Waldo, and C. E. Rexroad, Jr. 1995. Influence of prepubertal dietary regimen on mammary growth of Holstein heifers. J. Dairy Sci. 78:2709-2725.

Clark, R. D., and R. W. Touchberry. 1962. Effect of body weight and age at calving on milk production in Holstein cattle. J. Dairy Sci. 45:1500-1510. 
Connor, E. E., S. M. Barao, L. W. Douglass, S. A. Zinn, and G. E. Dahl. 1999. Prediction of bull performance using growth hormone (GH) response to GH-releasing hormone (GHRH). J. Anim. Sci. 77:2736-2741.

Early, R. J., B. W. McBride, and R. O. Ball. 1990. Growth and metabolism in somatotropin-treated steers: II. Carcass and noncarcass tissue components and chemical composition. J Anim. Sci. 68:4144-4152.

Elsasser, T. H., T. S. Rumsey, and A. C. Hammond. 1989. Influence of diet on basal and growth hormone-stimulated plasma concentrations of IGF-I in beef cattle. J. Anim. Sci. 67:128-137.

Grings, E. E., D. M. deAvila, R. G. Eggert, and J. J. Reeves. 1990. Conception rate, growth, and lactation of dairy heifers treated with recombinant somatotropin. J. Dairy Sci. 73:73-77.

Hardville, D. A., and C. R. Henderson. 1966. Interrelationships among age, body weight, and production traits during first lactation of dairy cattle. J. Dairy Sci. 49:1254-1261.

Hart, I. C. 1983. Endocrine control of nutrient partition in lactating ruminants. Proc. Nutr. Soc. 42:181-186.

Heinrichs, A. J., and G. L. Hargrove. 1987. Standards of weight and height for Holstein heifers. J. Dairy Sci. 70:653-660.

Houseknecht, K. L., D. E. Bauman, D. G. Fox, and D. F. Smith 1992. Abomasal infusion of casein enhances nitrogen retention in somatotropin-treated steers. J. Nutr. 122:1717-1725.

Keown, J. F., and R. W. Everett. 1986. Effect of days carried calf, days dry, and weight of first calf heifers on yield. J. Dairy Sci. 69:1891-1896.

Kurz, S. G., R. M. Dyer, Y. Hu, M. D. Wright, and M. L. Day. 1990. Regulation of luteinizing hormone secretion in prepubertal heifer fed an energy-deficient diet. Biol. Reprod. 43:450-456.

Lammers, B. P., and A. J. Heinrichs. 2000. The response of altering the ratio of dietary protein to energy on growth, feed efficiency, and mammary development in rapidly growing dairy heifers. J. Dairy Sci. 83:977-983.

Markusfeld, O., and E. Ezra. 1993. Body measurements, metritis, and postpartum performance of first lactation dairy cows. J. Dairy Sci. 76:3771-3777.

McShane, T. M., K. K. Schillo, J. A. Boling, N. W. Bradley, and J. B. Hall. 1989. Effects of recombinant DNA-derived somatotropin and dietary energy intake in development of beef heifers: I. Growth and puberty. J. Anim. Sci. 67:2230-2236.

Moallem, U., G. E. Dahl E. K. Duffey, A. V. Capuco, D. L. Wood, K. R. McLeod, R. L. Baldwin, VI, and R. A. Erdman. 2004. Bovine somatotropin and rumen-undegradable protein effects in prepubertal dairy heifers: Effects on body composition and organ and tissue weights. J. Dairy Sci. 87:3869-3880.
National Research Council. 1989. Nutrient Requirements of Dairy Cattle. 6th rev. ed. Natl. Acad. Sci., Washington, DC.

National Research Council. 2001. Nutrient Requirement of Dairy Cattle. 7th Rev. Ed. Natl. Acad. Sci., Washington, DC.

Radcliff, R. P., M. J. Vandehaar, A. L. Skidmore, L. T. Chapin, B. R. Radke, J. W. Lloyd, E. P. Stanisiewski, and H. A. Tucker. 1997. Effects of diet and bovine somatotropin on heifer growth and mammary development. J. Dairy Sci. 80:1996-2003.

Radcliff, R. P., M. J. Vandehaar, A. L. Skidmore, L. T. Chapin, B. R. Radke, J. W. Lloyd, E. P. Stanisiewski, and H. A. Tucker. 2000. Effects of diet and injection of bovine somatotropin on prepubertal growth and first-lactation milk yields of Holstein cows. J. Dairy Sci. 83:23-29.

Sandles, L. D., and C. J. Peel. 1987. Mammogenesis and first lactation milk yield of identical-twin heifers following pre-pubertal administration of bovine growth hormone. Anim. Prod. 45:349-357.

SAS User's Guide: Statistics, Version 8.0 Edition. 2000. SAS Inst. Inc., Cary, NC.

Schillo, K. K., J. B. Hall, and S. M. Hileman. 1992. Effect of nutrition and season on the onset of puberty in the beef heifer. J. Anim. Sci. 70:3994-4005.

Sejrsen, K. 1994. Relationships between nutrition, puberty and mammary gland development in cattle. Proc. Nutr. Soc. 53:103-111.

Sejrsen, K., J. T. Huber, and H. A. Tucker, and R. M. Akers. 1982. Influence of nutrition on mammary development in pre-and postpubertal heifers. J. Dairy Sci. 65:793-800.

Sieber, M., A. E. Freeman, and D. H. Kelley. 1988. Relationships between body measurements, body weight, and productivity in Holstein dairy cows. J. Dairy Sci. 71:3437-3445.

Silva, L. F. P., M. J. VandeHaar, B. K. Whitlock, R. P. Radcliff, and H. A. Tucker. 2002. Short Communication: Relationship between body growth and mammary development in dairy heifers. J. Dairy Sci. 85:2600-2602.

Spicer, L. J., J. J. Ireland, and J. F. Roche. 1981. Changes in serum $\mathrm{LH}$, progesterone and specific binding of ${ }^{125} \mathrm{I}-\mathrm{hCG}$ to luteal cells during regression and development of bovine corpora lutea. Biol. Reprod. 25:832-841.

Tucker, H. A. 1987. Quantitative estimates of mammary growth during various physiological states: A review. J. Dairy Sci. 70:1958-1966.

Van Amburgh, M. E., D. M. Galton, D. E. Bauman, R. W. Everett, D. G. Fox, L. E. Chase, and H. N. Erb. 1998. Effects of three prepubertal body growth rates on performance of Holstein heifers during first lactation. J. Dairy Sci. 81:527-538.

Waldo, D. R., H. F. Tyrrell, A. V. Capuco, and C. E. Rexroad. 1997. Components of growth in Holstein heifers fed either alfalfa or corn silage diets to produce two daily gains. J. Dairy Sci. 80:1674-1684. 